\title{
Actinomyces howellii, a New Species from the Dental Plaque of Dairy Cattle
}

\author{
V. E. DENT $\dagger$ AND R. A. D. WILLIAMS* \\ The London Hospital Medical College, Department of Biochemistry, London EI 2AD, United Kingdom
}

\begin{abstract}
Five strains of actinomyces isolated from the dental plaque of cattle were assigned presumptively to the genus Actinomyces on the basis of Gram staining, colonial and cellular morphology, fermentation reactions, and acid end products of metabolism. This assignment was confirmed by the molar composition of peptidoglycans. The isolates formed a homogeneous group on the basis of the sodium dodecyl sulfatepolyacrylamide electrophoresis patterns of their polypeptides, their cell wall carbohydrate constituents, and their deoxyribonucleic acid mean base compositions. They were also clearly related as determined by deoxyribonucleic acid-deoxyribonucleic acid homology, which distinguished them from strains of Actinomyces naeslundii, Actinomyces viscosus, and "Actinomyces denticolens." A new taxon, Actinomyces howellii, is proposed for these strains, the type strain of which is strain NCTC 11636.
\end{abstract}

Actinomyces is a genus whose normal habitat seems to be the oral cavities of humans and animals (13). As part of a study of the flora of dental plaque of a wide range of animals (4), presumptive Actinomyces were isolated and preserved. In an initial identification, most of the strains isolated were allotted to Actinomyces naeslundii or Actinomyces viscosus. No strains identifiable as Actinomyces bovis, the cause of "lumpy jaw" in cattle (13), were isolated from the plaque of the healthy cattle examined. However, a more detailed chemotaxonomic study revealed that the strains presumptively allocated to $A$. naeslundii, which were isolated from dairy cattle, possessed features quite distinct from those of $A$. naeslundii isolated from most other animals or culture collection strains of this species. One new taxon, "Actinomyces denticolens," has been proposed for one group of cattle isolates (5a). In this paper we describe a second new species from cattle plaque, Actinomyces howellii.

\section{MATERIALS AND METHODS}

Bacterial strains and their sources. Supragingival dental plaque was collected from the incisors of 15 dairy cattle at the National Institute for Research in Dairying, Shinfield, United Kingdom, suspensions were prepared, and bacteria were isolated, cultured, and purified as described previously (4). Five of the strains, each isolated from a different cow and provisionally identified as $A$. naeslundii, were compared with strains of $A$. naeslundii, "A. denticolens," and $A$. viscosus (Table 1).

Media and growth conditions. Cultures were maintained anaerobically at $37^{\circ} \mathrm{C}$ under $10 \%$ (vol/vol) carbon dioxide and $20 \%$ (vol/vol) hydrogen in nitrogen. The basal broth used contained (per liter) $20 \mathrm{~g}$ of proteose peptone (Oxoid Ltd., London, United Kingdom), $5 \mathrm{~g}$ of yeast extract (Difco Laboratories, Detroit, Mich.), $5 \mathrm{~g}$ of $\mathrm{NaCl}$, and $1 \mathrm{~g}$ of $\mathrm{Na}_{2} \mathrm{HPO}_{4}$ and was adjusted to $\mathrm{pH}$ 7.6. The fermentation broths used were the basal medium supplemented with filtersterilized (Millex type HA; pore size, $0.45 \mu \mathrm{m}$; Millipore UK Ltd., Harrow, United Kingdom) carbohydrates at final concentrations of $10 \mathrm{~g} /$ liter. All broths were inoculated with 4 drops of a starter culture containing $5 \mathrm{~g}$ of glucose per liter and were incubated for 7 days at $37^{\circ} \mathrm{C}$. The final $\mathrm{pH}$ values

\footnotetext{
* Corresponding author.

† Present address: Queen's University, Department of Botany, Belfast, BT7 1NN, United Kingdom.
}

were measured electrometrically. The acid end products were determined as described previously (4).

Preparation of biomass. Cells for deoxyribonucleic acid (DNA) purification were grown overnight in a medium containing $19 \mathrm{~g}$ of brain heart infusion (GIBCO Europe Ltd., Paisley, United Kingdom), $7.5 \mathrm{~g}$ of proteose peptone (Oxoid), $4.5 \mathrm{~g}$ of Trypticase (BBL Microbiology Systems, Wembley, United Kingdom), $9 \mathrm{~g}$ of glucose, and $3 \mathrm{~g}$ of yeast extract (Difco) dissolved in $950 \mathrm{ml}$ of water at $\mathrm{pH}$ 6.5. Before inoculation, $50 \mathrm{ml}$ of a sterile $10 \%$ solution of sodium bicarbonate was added to the medium to give a final concentration of $5 \mathrm{~g} /$ liter. In the late exponential growth phase, the exact time being strain dependent, $40 \mathrm{U}$ of benzylpenicillin was added per liter of culture, and incubation continued for 1 h. The cells were harvested by centrifugation at $10,000 \times g$, washed by suspension in $0.15 \mathrm{M} \mathrm{NaCl}-10 \mathrm{mM}$ ethylenediaminetetraacetate $(\mathrm{pH} 7.0)$, recentrifuged, and stored at $-20^{\circ} \mathrm{C}$. The cells to be used for purification of peptidoglycan were grown for 3 to 4 days in static culture in filled bottles without excluding air and were frozen unwashed. The biomass used for the analysis of wall carbohydrate components and for the preparation of soluble proteins was grown in the same way but was washed twice by suspension in distilled water and recentrifugation. For extraction of proteins for sodium dodecyl sulfate (SDS)-polyacrylamide gel electrophoresis, cells were grown at $37^{\circ} \mathrm{C}$ for 2 days in the medium used for DNA purification, except that penicillin was not added.

Cell wall analysis. Peptidoglycan was prepared by the rapid method of Schleifer and Kandler (12), and $2 \mathrm{mg}$ was hydrolyzed with $0.5 \mathrm{ml}$ of $4 \mathrm{M}$ hydrochloric acid at $105^{\circ} \mathrm{C}$ for $16 \mathrm{~h}$. The dried hydrolysate was dissolved in $5 \mathrm{ml}$ of $0.1 \mathrm{M}$ hydrochloric acid, and $100 \mu \mathrm{l}$ was analyzed with a model $5 \mathrm{D}$ amino acid analyzer (Locarte Co., London, United Kingdom) by eluting with sodium citrate buffers at $\mathrm{pH} 3.25,4.25$, and 9.5 successively. For qualitative analysis hydrolysates were examined by two-dimensional paper chromatography (6) and high-voltage electrophoresis in pyridine-acetic acid buffer at pH 5.2 (1).

For the detection of carbohydrates, walls were prepared by shaking a suspension of cells in water with grade 12 Ballotini beads in a tissue disintegrator (Mickle Engineering, Gomshall, United Kingdom) for $6 \mathrm{~h}$ at $4^{\circ} \mathrm{C}$. The walls were washed from the Ballotini beads, the unbroken cells were removed by centrifugation at $3,000 \times g$, and the walls were sedimented by centrifugation at $17,000 \times g$ and suspended in 
TABLE 1. Designations and sources of Actinomyces strains studied

\begin{tabular}{|c|c|c|}
\hline Strain & Origin & Source $^{a}$ \\
\hline \multicolumn{3}{|l|}{ A. howellii } \\
\hline $\operatorname{NCTC} 11636^{\mathrm{T}}\left(=\mathrm{Sh} 7 / 4276^{\mathrm{T}}\right)^{b}$ & $\begin{array}{l}\text { Dental plaque of } \\
\text { dairy cattle }\end{array}$ & Dent \\
\hline $\operatorname{Sh} 2 / 3960$ & $\begin{array}{l}\text { Dental plaque of } \\
\text { dairy cattle }\end{array}$ & Dent \\
\hline Sh14/4587 & $\begin{array}{l}\text { Dental plaque of } \\
\text { dairy cattle }\end{array}$ & Dent \\
\hline Sh6/4159 & $\begin{array}{l}\text { Dental plaque of } \\
\text { dairy cattle }\end{array}$ & Dent \\
\hline Sh10/4422 & $\begin{array}{l}\text { Dental plaque of } \\
\text { dairy cattle }\end{array}$ & Dent \\
\hline \multicolumn{3}{|l|}{ "A. denticolens" } \\
\hline NCTC $11490^{\mathrm{T}}\left(=\mathrm{Sh} 8 / 4303^{\mathrm{T}}\right)$ & $\begin{array}{l}\text { Dental plaque of } \\
\text { dairy cattle }\end{array}$ & Dent \\
\hline $\mathrm{Sh} 7 / 4277$ & $\begin{array}{l}\text { Dental plaque of } \\
\text { dairy cattle }\end{array}$ & Dent \\
\hline $\operatorname{Sh} 5 / 4040$ & $\begin{array}{l}\text { Dental plaque of } \\
\text { dairy cattle }\end{array}$ & Dent \\
\hline Sh8/4313 & $\begin{array}{l}\text { Dental plaque of } \\
\text { dairy cattle }\end{array}$ & Dent \\
\hline \multicolumn{3}{|l|}{ A. naeslundii } \\
\hline BBI/1958 & $\begin{array}{l}\text { Dental plaque of } \\
\text { bush baby }\end{array}$ & Dent \\
\hline $\mathrm{SM} / 1643$ & $\begin{array}{l}\text { Dental plaque of } \\
\text { spider monkey }\end{array}$ & Dent \\
\hline $\mathrm{SM} / 1647$ & $\begin{array}{l}\text { Dental plaque of } \\
\text { spider monkey }\end{array}$ & Dent \\
\hline OU2/1912 & $\begin{array}{l}\text { Dental plaque of } \\
\text { orangutan }\end{array}$ & Dent \\
\hline $\mathrm{SM} / 1726$ & $\begin{array}{l}\text { Dental plaque of } \\
\text { spider monkey }\end{array}$ & Dent \\
\hline $\begin{array}{l}\text { A. viscosus } \\
\operatorname{T6}^{\mathrm{T}}\left(=\text { ATCC } 15987^{\mathrm{T}}\right)\end{array}$ & Hamster mouth & Bowden \\
\hline
\end{tabular}

"Dent, V. E. Dent, London Zoo, London, United Kingdom; Bowden. G. H. Bowden, Winnepeg, Canada.

${ }^{b} \mathrm{~T}=$ type strain.

a solution containing $10 \mathrm{mg}$ of protease (Sigma Ltd., Poole, United Kingdom) per $100 \mathrm{ml}$ and $0.05 \mathrm{M}$ phosphate buffer $(\mathrm{pH} 8.0)$ at $37^{\circ} \mathrm{C}$ for $16 \mathrm{~h}$. The residue was washed three times with water by centrifugation and then freeze-dried. Hydrolysis was with $1 \mathrm{M}$ sulfuric acid $(0.5 \mathrm{ml} / 10 \mathrm{mg})$ for $1 \mathrm{~h}$ at $100^{\circ} \mathrm{C}$; the acid was neutralized with Dowex $2-\mathrm{X} 8$ resin in the carbonate form. Qualitative analysis of the carbohydrates involved paper chromatography with $n$-butanol-pyridine-water $(60: 40: 30, \mathrm{vol} / \mathrm{vol})$ and thin-layer chromatogra- phy on silica gel impregnated with $0.03 \%$ (vol/vol) boric acid, using solvent systems 13 and 42 of Lato et al. (7). The papers were dipped in aniline-phthalate (11), and the thin-layer chromatography plates were sprayed with 4-aminobenzoic acid reagent (8). The sensitivity of detection was increased by examining the chromatograms with ultraviolet light (366 $\mathrm{nm}$ ).

SDS-polyacrylamide gel electrophoresis. Cells were washed and shaken with Ballotini beads in a Mickle tissue disintegrator for $1 \mathrm{~h}$. The supernatant was centrifuged at $17,000 \times g$ and then at $145,000 \times g$. The cell-free extracts were electrophoresed in $10 \%$ (wt/vol) SDS-polyacrylamide gels (15).

Isolation of DNA and determination of mean base composition. A cell paste $(5 \mathrm{~g})$ was suspended in $10 \mathrm{ml}$ of $1 \mathrm{M} \mathrm{NaCl}$ supplemented with $1 \mathrm{mg}$ of proteinase XIV (Sigma) and $1 \mathrm{ml}$ of $25 \%$ SDS and was disrupted by pressing at $8,000 \mathrm{lb} / \mathrm{in}^{2}$ with a French pressure cell (Aminco, Silver Spring, Md.) into $100 \mathrm{ml}$ of $1 \mathrm{M} \mathrm{NaCl}$ at $60^{\circ} \mathrm{C}$. To this viscous suspension 9 $\mathrm{ml}$ of $25 \%$ SDS was added, and the whole mixture was incubated at $60^{\circ} \mathrm{C}$ for $10 \mathrm{~min}$. The cooled suspension was shaken with an equal volume of $4 \%$ isopentanol in chloroform for $15 \mathrm{~min}$ and centrifuged at $5,000 \times \mathrm{g}$ for $30 \mathrm{~min}$. The DNA was spooled from the separated aqueous layer with 2 volumes of cold ethanol, dissolved in dilute saline citrate (DSC; $0.1 \times \mathrm{SSC}$ [ $1 \times \mathrm{SSC}$ is $0.15 \mathrm{M} \mathrm{NaCl}$ plus $0.015 \mathrm{M}$ sodium citrate]), and centrifuged at $10,000 \times g$ for $20 \mathrm{~min}$. Ribonuclease A (Sigma) was dissolved $(1 \mathrm{mg} / \mathrm{ml})$ in $0.15 \mathrm{M}$ $\mathrm{NaCl}\left(\mathrm{pH} \mathrm{5.0)}\right.$ and incubated at $80^{\circ} \mathrm{C}$ for $10 \mathrm{~min}$. The DNA was incubated at $37^{\circ} \mathrm{C}$ with the cooled enzyme $(5 \mathrm{mg}$ of ribonuclease per $100 \mathrm{ml}$ of DNA solution). Protease XIV (Sigma) was preincubated for $1 \mathrm{~h}$ at $37^{\circ} \mathrm{C}$ dissolved in $0.15 \mathrm{M}$ $\mathrm{NaCl}-10 \mathrm{mM}$ ethylenediaminetetraacetate $(\mathrm{pH}$ 8.0) at a concentration of $5 \mathrm{mg} / \mathrm{ml}$. The enzyme $(0.25 \mathrm{mg} / \mathrm{ml})$ was added to the DNA solution, and the mixture was incubated for $1 \mathrm{~h}$ at $37^{\circ} \mathrm{C} ; 0.1$ volume of $2 \%$ deoxycholate was added, and the mixture was incubated for $1 \mathrm{~h}$ at $37^{\circ} \mathrm{C}$ and then overnight at $4^{\circ} \mathrm{C}$. The DNA was precipitated with 2 volumes of cold isopropanol and then dissolved in DSC at $4^{\circ} \mathrm{C}$. DNA base composition was determined by melting the DNA in DSC and measuring the absorbance at $260 \mathrm{~nm}$ with a Gilford model 240 recording spectrophotometer. Thermal melting $\left(T_{m}\right)$ values obtained from the melting curves were used to calculate the base composition according to the following relationship: guanine-plus-cytosine content $=50.9+$ $2.08\left(T_{m}-74.9\right)$, where $74.9^{\circ} \mathrm{C}$ was the $T_{m}$ obtained for Escherichia coli DNA in DSC (10).

DNA-DNA hybridization. DNA to be used in hybridization

TABLE 2. Physiological reactions, cell wall carbohydrates, and peptidoglycan components of $A$. howellii strains ${ }^{a}$

\begin{tabular}{|c|c|c|c|c|c|c|c|c|c|c|c|c|c|c|c|c|c|c|c|c|}
\hline \multirow[b]{2}{*}{ Strain } & \multicolumn{9}{|c|}{ Acid production from: } & \multicolumn{5}{|c|}{ Cell wall carbohydrates } & \multicolumn{6}{|c|}{ Cell wall amino acids and amino sugars } \\
\hline & 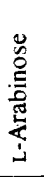 & $\begin{array}{l}\stackrel{\mathscr{E}}{\Xi} \\
\stackrel{\stackrel{\Xi}{\Xi}}{\Sigma}\end{array}$ & 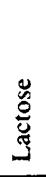 & 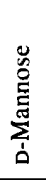 & $\begin{array}{l}\mathscr{U} \\
\stackrel{0}{0} \\
\stackrel{0}{0} \\
\sum\end{array}$ & 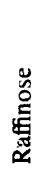 & 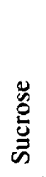 & 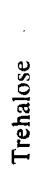 & $\begin{array}{l}\dot{y} \\
\dot{0} \\
\dot{x} \\
\dot{0}\end{array}$ & 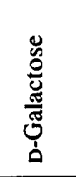 & 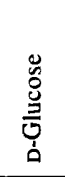 & 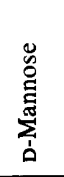 & 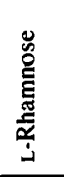 & 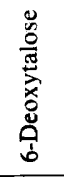 & 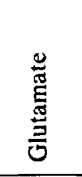 & 畩 & $\begin{array}{l}\stackrel{\mathscr{E}}{E} \\
\stackrel{.}{E} \\
5\end{array}$ & 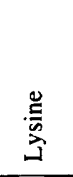 & 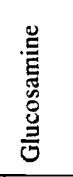 & 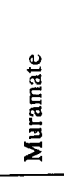 \\
\hline NCTC $11636^{\mathrm{T}}$ & + & $\mathrm{w}^{b}$ & w & w & - & w & $w$ & $w$ & $w$ & - & $t^{c}$ & - & + & - & + & + & + & + & + & + \\
\hline Sh $2 / 3960$ & + & + & + & + & W & + & + & w & + & $\mathrm{ND}^{d}$ & $\mathrm{ND}$ & ND & ND & ND & $2.00^{\circ}$ & 1.80 & 0.82 & 0.84 & 0.87 & 0.60 \\
\hline Sh14/4587 & - & w & - & + & w & w & + & - & $\mathrm{w}$ & - & + & - & + & - & 2.00 & 1.94 & 0.82 & 0.88 & 0.86 & 0.54 \\
\hline Sh6/4159 & + & + & w & - & + & + & + & - & - & - & + & - & + & - & 2.00 & 1.85 & 0.77 & 0.83 & 0.89 & 0.56 \\
\hline Sh10/4422 & + & + & $\mathbf{w}$ & + & + & + & + & + & + & - & + & - & + & - & + & + & + & + & + & + \\
\hline
\end{tabular}

a All strains fermented glucose; none fermented amygdalin, cellobiose, D-ribose, glycerol, myo-inositol, D-mannitol, L-rhamnose, salicin, or inulin.

${ }^{b} \mathrm{w}$, Weak fermentation.

' $t$, Trace detected.

${ }^{d}$ ND, Not determined.

e Molar ratio. 


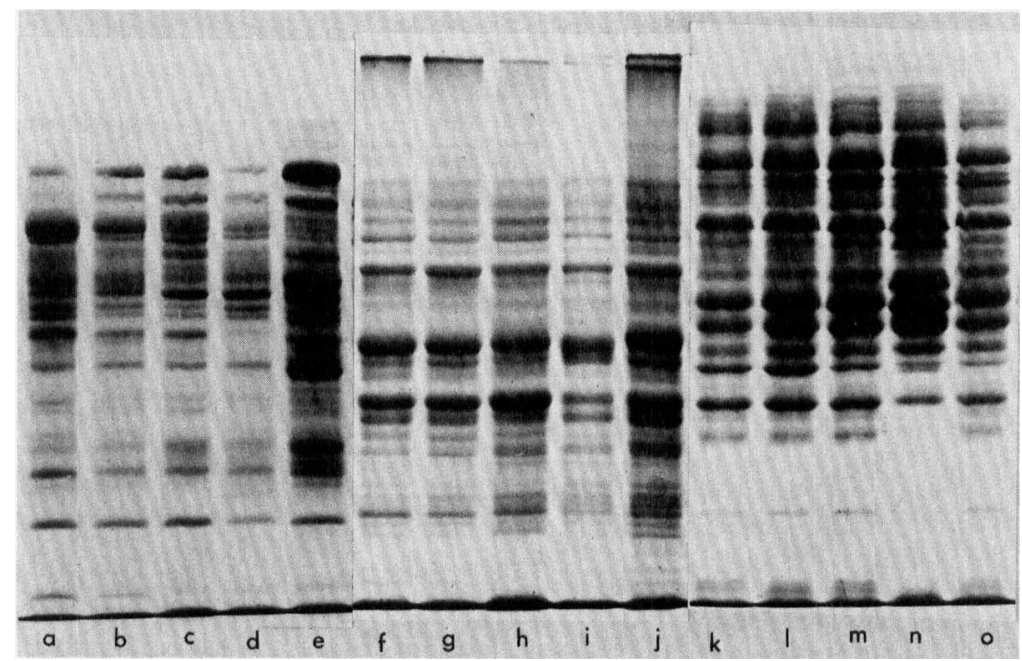

FIG. 1. SDS-polyacrylamide gel electrophoresis of polypeptides from Actinomyces strains. Lanes a through e, A. howellii strains Sh2/ 3960, Sh14/4587, Sh6/4159, NCTC 11636 ${ }^{\mathrm{T}}$, and Sh10/4422, respectively; lanes $\mathrm{f}$ through $\mathrm{j}$, A. naeslundii strains SM/1643, SM/1647, OU3/1912, $\mathrm{BBI} / 1958$, and SM/1726, respectively; lanes k through o, "A. denticolens" strains NCTC 11490 ${ }^{\mathrm{T}}$, Sh7/4277, Sh5/4040, Sh8/4313, and Sh7l 4250 , respectively.

was purified by centrifugation in a cesium chloride gradient. A DNA solution $(8 \mathrm{ml})$ in $1 \times$ SSC was mixed with $8 \mathrm{~g}$ of cesium chloride (Bethesda Research Laboratories, Cambridge, United Kingdom) and $0.8 \mathrm{ml}$ of ethidium bromide ( 5 $\mathrm{mg} / \mathrm{ml}$ in water). The gradient was established by centrifugation at $150,000 \times g$ for 40 to $48 \mathrm{~h}$. The DNA was detected as an ethidium bromide-binding band. The DNA was dissolved in $0.1 \times \mathrm{SSC}$, and the ethidium bromide was removed by extraction with $n$-butanol. Pure DNA was spooled out with 2 volumes of ethanol and dialyzed against $3 \times$ SSC. The concentration of DNA was determined by absorption at 260 $\mathrm{nm}$ with a Perkin-Elmer model 402 scanning spectrophotometer. DNA that was sufficiently pure for hybridization had an absorbance ratio $(280 \mathrm{~nm} / 260 \mathrm{~nm})$ approaching 2 .

Pure DNA was labeled with ${ }^{3} \mathrm{H}$-labeled deoxycytidine triphosphate by nick translation (nick translation kit TRK 700; Amersham International, Amersham, United Kingdom). The specific activity obtained varied between $8 \times 10^{5}$ and $1.2 \times 10^{6} \mathrm{cpm} / \mu \mathrm{g}$ of DNA.

DNA was loaded onto nitrocellulose filters, and the hybridization procedures of Back and Stackebrandt (2) and Stackebrandt and Feidler (14) were used. Incubation mixtures were comprised of $0.05 \mu \mathrm{g}$ of $\left[{ }^{3} \mathrm{H}\right] \mathrm{DNA}$ dissolved in
$200 \mu \mathrm{l}$ of $3 \times$ SSC containing $25.5 \%$ formamide and a $5-\mathrm{mm}$ filter disk loaded with 9 to $15 \mu \mathrm{g}$ of denatured DNA and were shaken at $60^{\circ} \mathrm{C}$ for $20 \mathrm{~h}$. The radioactivity that remained on a filter after washing twice with $1.0 \mathrm{ml}$ of cold $3 \times \mathrm{SSC}$ and drying at $80^{\circ} \mathrm{C}$ was counted in $3 \mathrm{ml}$ of cocktail $\mathrm{O}$ (British Drug Houses, Poole, United Kingdom) with an Intertechnique model SL 3000 liquid scintillation counter.

\section{RESULTS AND DISCUSSION}

The five strains isolated from the dental plaque of dairy cattle were presumptively identified as $A$. naeslundii. These organisms are short (1.5 to 5 by $0.8 \mu \mathrm{m})$, gram-positive, nonsporulating, nonmotile rods which grow under $80 \%$ nitrogen-10\% hydrogen-10\% carbon dioxide as smooth, white, shiny, translucent colonies that are convex, have entire margins, and are up to $2 \mathrm{~mm}$ in diameter on blood agar plates after 3 to 5 days of incubation.

Physiological reactions. The strains were facultatively anaerobic and did not produce catalase, but growth in liquid media was stimulated by the presence of carbon dioxide. Fermentation tests (Table i) were dominated by negative results for all strains with one-half of the carbohydrates tested. The only carbohydrate fermented by all of the strains

TABLE 3. DNA relatedness values among A. howellii strains and other Actinomyces species

\begin{tabular}{|c|c|c|c|c|c|c|c|}
\hline \multirow[b]{2}{*}{ Strain } & \multirow[b]{2}{*}{$\begin{array}{c}T_{m} \text { in } 0.1 \times \\
\text { SSC }\left({ }^{\circ} \mathrm{C}\right)\end{array}$} & \multirow{2}{*}{$\begin{array}{l}\text { Guanine-plus- } \\
\text { cytosine con- } \\
\text { tent of DNA } \\
\text { (mol\%) }\end{array}$} & \multicolumn{5}{|c|}{$\%$ Homology with $\left[{ }^{3} \mathrm{H}\right] \mathrm{DNA}$ from: } \\
\hline & & & $\begin{array}{l}\text { A. howellii } \\
\text { Sh } 7 / 4276^{\mathrm{T}}\end{array}$ & $\begin{array}{l}\text { A. naeslundii } \\
\mathrm{BBI} / 1958\end{array}$ & $\begin{array}{l}\text { A. naeslundii } \\
\text { SM/1643 }\end{array}$ & $\begin{array}{c}\text { A. viscosus } \\
{ }_{\mathrm{T}} \mathrm{T}^{\mathrm{T}}\end{array}$ & $\begin{array}{l}\text { "A. dentico- } \\
\text { lens" Sh7/4277 }\end{array}$ \\
\hline \multicolumn{8}{|l|}{ A. howellii } \\
\hline NCTC $11636^{\mathrm{T}}\left(=\operatorname{Sh} 7 / 4276^{\mathrm{T}}\right)$ & 83.1 & 66.7 & 100 & 17 & 31 & 19 & 31 \\
\hline $\operatorname{Sh} 2 / 3960$ & 83.3 & 66.9 & 98 & 20 & 23 & 19 & 22 \\
\hline Sh14/4587 & 82.7 & 65.9 & 120 & 26 & 46 & 31 & 37 \\
\hline Sh6/4159 & 83.4 & 67.3 & 93 & 22 & 29 & 21 & 28 \\
\hline Sh10/4422 & 83.2 & 67.0 & 99 & 25 & 29 & 17 & 28 \\
\hline \multicolumn{8}{|l|}{ A. naeslundii } \\
\hline $\mathrm{BBI} / 1958$ & 82.5 & 65.9 & 20 & 100 & & 30 & \\
\hline $\mathrm{SM} / 1643$ & 81.6 & 64.8 & 28 & & 100 & & \\
\hline A. viscosus $\mathbf{T}^{\mathbf{T}}\left(=\operatorname{ATCC} 15987^{\mathrm{T}}\right)$ & 82.8 & 66.1 & 26 & 38 & & 100 & \\
\hline "A. denticolens"'Sh7/4277 & 83.5 & 67.5 & 26 & & 26 & & 100 \\
\hline $\begin{array}{l}\text { Lactobacillus odontolyticus } \\
\text { NCTC } 1407\end{array}$ & & & 2 & 6 & 2 & 2 & 2 \\
\hline
\end{tabular}


was glucose. For the nine other substrates commonly fermented, weak or negative results were obtained with one or more of the isolates. The fermentation results showed clear distinctions between the strains described here and " $A$. denticolens" strains (5a), which usually ferment inositol, inulin, ribose, and salicin but do not ferment xylose. The strains described here were distinguished from $A$. naeslundii strains, which fermented inositol, ribose, and salicin in our hands (Dent and Williams, unpublished data), although Slack and Gerencser reported that only $54 \%$ of their strains fermented ribose (13). The acid end products formed included acetic and lactic acids, as well as trace amounts of succinic acid.

Cell wall composition. The molar ratios of the components in the peptidoglycans of all species of Actinomyces except $\boldsymbol{A}$. bovis are unusual. The composition shown in Table 2 (glutamate-alanine-ornithine-lysine-glucosamine-muramate ratio approximately $2: 2: 1: 1: 1: 1)$ is consistent with the unusual glutamyl-ornithine cross-linkage type (12) and confirms the status of the strains described here as members of the genus Actinomyces. The carbohydrates of the cell walls comprise only glucose and rhamnose and, significantly, do not include 6-deoxytalose. In this respect there is a clear distinction from "A. denticolens," which contains rhamnose but no glucose (5a), and from $A$. naeslundii, which contains glucose, rhamnose, and 6-deoxytalose (5a). Other species of Actinomyces may also be distinguished from these strains by cell wall carbohydrates (13), but there are other grounds for recognizing that they are different.

SDS-polyacrylamide gel electrophoresis of polypeptides. The cluster of similar strains described in this paper was first recognized by the similar patterns which the strains produced on SDS-polyacrylamide gel electrophoresis plates (Fig. 1). This technique has been very valuable in isolating from heterogenous collections of strains clusters which have been described as "A. denticolens" (5a) and Lactobacillus animalis (5), both of which have been confirmed as separate species by other chemotaxonomic criteria and by DNADNA homology (Dent and Williams, unpublished data). The patterns obtained are somewhat variable among the five strains described here, as they are among the strains of " $A$. denticolens" and $A$. naeslundii, but the three types of patterns are so distinct from one another as to preclude any confusion among the three groups. SDS-polyacrylamide gel electrophoresis is an excellent screening technique, as are other electrophoretic separations of proteins (3).

DNA base composition and DNA-DNA hybridization. DNA base compositions were estimated by determining $T_{m}$ values in $0.1 \times \mathrm{SSC}$ and were calculated relative to the $T_{m}$ value of the DNA of $E$. coli strain B; the values obtained for the strains described in this paper are similar to the values obtained for "A. denticolens" and $A$. naeslundii in our laboratory. The DNA base composition of 65.9 to $67.3 \mathrm{~mol} \%$ guanine plus cytosine indicated a necessity to make comparisons with $A$. naeslundii, $A$. viscosus, and " $A$. denticolens" (Table 3). A. bovis, Actinomyces odontolyticus, and Actinomyces israelii all have lower mean base compositions and are quite different from the strains described here in physiological and chemotaxonomic properties. The results of DNA-DNA homology experiments represent the strongest evidence for the homogeneity of the newly described strains, their status as a genospecies, and their low homology with the other three species tested. Therefore, we propose that a new taxon be established, Actinomyces howellii.

Description of Actinomyces howellii sp. nov. Actinomyces howellii (how.ell'i.i. L. adj. howelii named after A. Howell, who studied oral actinomyces of animals, particularly Odontomyces [Actinomyces] viscosus) cells are gram positive, nonmotile, nonsporeforming, rod shaped, and $0.8 \mu \mathrm{m}$ wide by 1.5 to $5 \mu \mathrm{m}$ long. On horse blood agar plates after 3 to 5 days of anaerobic incubation at $37^{\circ} \mathrm{C}$, colonies are white, smooth, shiny, translucent, entire, convex, and up to $2 \mathrm{~mm}$ in diameter.

Catalase positive.

Facultatively anaerobic. Growth is stimulated by $\mathrm{CO}_{2}$ in liquid media. Acid end products are acetic and lactic acids, with traces of succinic acid.

Acid is produced from glucose, maltose, raffinose, and sucrose, but not from amygdalin, cellobiose, D-ribose, glycerol, inositol, D-mannitol, L-rhamnose, salicin, or inulin. Most strains ferment L-arabinose, lactose, D-mannose, melibiose, trehalose, and D-xylose. The composition of the peptidoglycan is consistent with a structure comprising the glutamyl-ornithine cross-link found in most other Actinomyces species. The cell wall carbohydrates include glucose and rhamnose but not 6-deoxytalose.

Base composition of DNA: 65.9 to 67.3 mol\% guanine plus cytosine.

Type strain: strain Sh7/4276 (= NCTC 11636).

\section{ACKNOWLEDGMENTS}

The strains described in this paper were isolated from animal dental plaque under a grant provided by Cadbury-Schweppes. The chemotaxonomic studies were carried out with the support of grants G979295/SB and G8207598/SB from the Medical Research Council.

We thank E. Stackebrandt for his assistance with the DNA-DNA hybridization technique.

\section{LITERATURE CITED}

1. Atfield, G. N., and C. J. O. R. Morris. 1961. Analytical separations by high voltage paper electrophoresis. Amino acids in protein hydrolysates. Biochem. J. 81:606-614.

2. Back, W., and E. Stackebrandt. 1978. DNS-DNS Homologiestudien innerhalb der Gattung Pediococcus. Arch. Microbiol. 118:79-85.

3. Biavati, B., V. Scardovi, and W. E. C. Moore. 1982. Electrophoretic patterns of proteins in the genus Bifidobacterium and proposal of four new species. Int. J. Syst. Bacteriol. 32:358-373.

4. Dent, V. E. 1979. The bacteriology of dental plaque from a variety of zoo-maintained mammalian species. Arch. Oral Biol. 24:277-282.

5. Dent, V. E., and R. A. D. Williams. 1982. Lactobacillus animalis sp. nov., a new species of Lactobacillus from the alimentary canal of animals. Zentralbl. Bakteriol. Parasitenkd. Infektionskr. Hyg. Abt. 1 Orig. Reihe C 3:377-386.

5a.Dent, V. E., and R. A. D. Williams. 1984. Actinomyces denticolens Dent \& Williams sp. nov.: a new species from the dental plaque of cattle. J. Appl. Bacteriol. 56:183-192.

6. Hardy, T. L., D. O. Holland, and J. H. C. Naylor. 1955. Onephase solvent mixtures for the separation of amino acids. Anal. Chem. 27:971-973.

7. Lato, M., B. Brunelli, and G. Ciuffini. 1968. Bidimensional thinlayer chromatography of carbohydrates on silica gel impregnated with boric acid. J. Chromatogr. 34:26-34.

8. Menzies, S., and J. N. Mount. 1975. Advantages of silica gel as a medium for rapid thin-layer chromatography of neutral sugars. Med. Res. Technol. 32:269-276.

9. Moore, W. E. C., D. E. Hash, L. V. Holdeman, and E. P. Cato. 1980. Polyacrylamide slab gel electrophoresis of soluble proteins for studies of bacterial floras. Appl. Environ. Microbiol. 39:900-907.

10. Owen, R. J., and L. R. Hill. 1979. The estimation of base compositions, base pairing and genome sizes of bacterial deoxyribonucleic acids, p. 277-296. In F. A. Skinner and D. W. Lovelock (ed.), Identification methods for microbiologists. SAB Technical Series No. 14. Academic Press, Inc., London. 
11. Partridge, S. M. 1949. Aniline hydrogen phthalate as a spraying reagent for chromatography of sugars. Nature (London) 164:433.

12. Schleifer, K. H., and O. Kandler. 1972. Peptidoglycan types of bacterial cell walls and their taxonomic implications. Bacteriol. Rev. 36:407-477.

13. Slack, J. M., and M. A. Gerencser. 1975. Actinomyces, filamentous bacteria. Biology and pathogenicity. Burgess Publishing
Co., Minneapolis.

14. Stackebrandt, E., and F. Fiedler. 1979. DNA-DNA homology studies among strains of Arthrobacter and Brevibacterium. Arch. Microbiol. 120:289-295.

15. Swindlehurst, C. A., H. N. Shah, C. W. Parr, and R. A. D. Williams. 1977. Sodium dodecyl sulfate polyacrylamide gel electrophoresis of polypeptides from Bacteroides melaninogenicus. J. Appl. Bacteriol. 43:319-324. 